\title{
Antiradical and Lipid Peroxidation Inhibitory Activity of Ripe and Unripe Fruit of Rubus steudneri Schweinf. (Rosaceae)
}

\author{
Raghavendra H.L ${ }^{1 *}$, Prashith Kekuda T.R ${ }^{2}$
}

\section{Raghavendra H.L ${ }^{1 *}$, Prashith Kekuda T.R ${ }^{2}$}

'Department of Biochemistry, School of Medicine, Wollega University, Nekemte, ETHIOPIA.

${ }^{2}$ Department of Microbiology, S.R.N.M.N College of Applied Sciences, N.E.S

Campus, Balraj Urs Road, Shivamogga, Karnataka, INDIA.

Correspondence

\section{Dr. H.L. Raghavendra}

Department of Biochemistry, School of Medicine, Wollega University, Nekemte, ETHIOPIA.

Phone no : +251922253091

E-mail: raghu.biogem@gmail.com

History

- Submission Date: 11-02-2018;

- Review completed: 22-02-2018.

- Accepted Date: 08-03-2018

DOI : 10.5530/pj.2018.4.139

Article Available online

http://www.phcogj.com/v10/i4

\section{Copyright}

(C) 2018 Phcog.Net. This is an openaccess article distributed under the terms of the Creative Commons Attribution 4.0 International license.

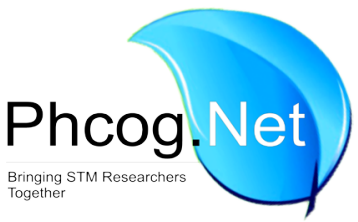

\begin{abstract}
Objectives: A free radical is a molecular species characterized by the presence of an unpaired electron in its outer orbital. Free radicals are highly reactive and are known to damage biomolecules including lipids resulting in a myriad of pathophysiological conditions. The present investigation was carried out to screen antiradical and lipid peroxidation inhibitory activity of ripe and unripe fruit of $R$. steudneri. Methods: The powdered ripe and unripe fruit materials were extracted by maceration process using methanol. Antiradical activity of extracts was evaluated by DPPH and hydroxyl radical scavenging assays. Lipid peroxidation inhibition assay was carried out by estimating the thiobarbituric acid reactive substances. Both ripe and unripe fruit extracts were screened for the presence of phytochemicals viz. alkaloids, flavonoids, tannins, phenolic compounds, saponins, glycosides, sterols and triterpenoids by standard tests. Results: Preliminary phytochemical analysis indicated that both ripe and unripe fruit extracts contain saponins, alkaloids, phenolic compounds, flavonoids, tannins, sterols and triterpenoids. When compared to unripe fruit extract, ripe fruit extract displayed marked scavenging of DPPH and hydroxyl radicals and inhibition of lipid peroxidation as indicated by lower $\mathrm{IC}_{50}$ values. Conclusion: Overall, ripe fruit extract displayed marked free radical scavenging and lipid peroxidation inhibitory activity. The presence of phenolic and flavonoid compounds in the extracts might be responsible for observed bioactivities of ripe and unripe fruit of R. steudneri.

Key words: Rubus steudneri Schweinf, Maceration, Phytochemical, Free radical, Lipid peroxidation.
\end{abstract}

\section{INTRODUCTION}

A free radical is a molecular species characterized by the presence of an unpaired electron in its outermost orbital. The radicals derived from oxygen as well as from nitrogen are toxic, damaging and include reactive species such as hydroxyl radical, superoxide radical, peroxyl radical, peroxy nitrite radical, hypochlorous acid, hydrogen peroxide. These radicals are shown to play significant physiological roles such as regulation of signal transduction and gene expression, signaling molecules, receptor activation and nuclear transduction. However, increased production of these reactive species exerts a damaging effect on biomolecules such as nucleic acids, proteins and lipids resulting in oxidative damage which is implicated in pathophysiological conditions such as cardiovascular diseases, neurodegenerative diseases, ageing and cancer. Strong restrictions have been placed on the use of synthetic antioxidants such as BHT and BHA due to their suspected carcinogenic effects. Hence, much interest is devoted on searching potential alternatives for synthetic antioxidants. Plants and their metabolites (in particular polyphenolic compounds) are shown to be the best resources for antioxidants. ${ }^{1-6}$

The plant Rubus steudneri Schweinf. (Commonly known as gora) belongs to the family Rosaceae. It is a scandent shrub (Figure 1) characterized by deeply furrowed stems that are greyish-tomentose and covered with stellate hairs or sometimes with prickles. The leaves are trifoliolate, doubly serrate, glabrate above and densely whitish-tomentose below. Inflorescence is a terminal panicle, much-branched and the branches are glandular-tomentose. Petals are obovate-oblong, purplish and twice as long as the calyx. Fruits are edible and consumed. The plant is utilized ethno botanically as food as well as medicine. The decoction made from the roots is used as a remedy for indigestion, gastritis and diarrhoea. The plant is also used for treating diabetes mellitus. ${ }^{7,8}$ Various parts of the plant (viz. leaf, stem and fruit) form a diet for gorillas in Bwindi Impenetrable National Park, Uganda. ${ }^{9}$

Different parts of the plant are medicinally for reating rheumatism, stomachache, diarrhea and ough. ${ }^{10-13}$ Besides, the plant is also used as food ince it is edible and for other purposes such as rnamental purpose, as fence and for house construction. ${ }^{14-19}$ Literatures have shown that the plant exhibits bioactivities such as antioxidant, ${ }^{20,21}$ antimicrobial, ${ }^{7,12}$ and antiproliferative activities. ${ }^{21}$ When literatures were surveyed, it was found

Cite this article: Raghavendra HL, Kekuda PTR. Antiradical and Lipid Peroxidation Inhibitory Activity of Ripe and Unripe Fruit of Rubus steudneri Schweinf. (Rosaceae). Pharmacog J. 2018;10(4):81822. 
that the free radical scavenging activity and inhibition of lipid peroxidation of the plant especially fruits is not much investigated. Hence, the present investigation was conducted to evaluate radical scavenging and lipid peroxidation inhibitory activity of ripe and unripe fruit of R. steudneri.

\section{MATERIALS AND METHODS}

\section{Collection and Identification of plant}

The plant material was collected at around Nekemte, located in the East Welega Zone of the Oromia Region, Ethiopia. The plant was identified on the basis of its characteristics.

\section{Extraction}

The ripe and unripe fruits (undamaged) were collected, washed well to remove adhering extraneous matter and shade dried. The dried fruit materials were powdered in a blender. Extraction of ripe and unripe fruit powder was done by employing maceration process. A known quantity $(10 \mathrm{~g})$ of ripe and unripe fruit powder was added to separate containers followed by adding $100 \mathrm{ml}$ of methanol to both the containers. The containers were sealed, left for about $72 \mathrm{hr}$ and stirred occasionally. The contents were filtrated through clean muslin cloth and then through Whatman No. 1 filter paper. The filtrates were evaporated to dryness in rotary evaporator. ${ }^{22}$

\section{Phytochemical Analysis}

The ripe and unripe fruit extract was screened for the presence of phytochemicals viz. alkaloids, flavonoids, saponins, glycosides, tannins, triterpenoids and phytosterols by standard phytochemical tests..$^{23-25}$

\section{2,2-diphenyl-1-picrylhydrazyl (DPPH) radical scavenging activity}

The scavenging potential of different concentrations of ripe and unripe fruit extracts $(6.25-200 \mu \mathrm{g} / \mathrm{ml})$ against DPPH radicals is investigated by following the protocol of Chandrashekar et al. ${ }^{26}$ Ascorbic acid was used as reference standard. The absorbance of reaction mixtures was read at $517 \mathrm{~nm}$. The scavenging of DPPH radicals by extracts and ascorbic acid was determined using the formula:

Scavenging of DPPH radicals $(\%)=(C-T / C) \times 100$, where ' $C$ ' and ' $\mathrm{T}$ ' denotes the absorbance of DPPH control and absorbance of DPPH in presence of extract/standard. $\mathrm{IC}_{50}$ value for fruit extracts as well as ascorbic acid was calculated. $\mathrm{IC}_{50}$ value denotes the concentration of fruit extract/ascorbic acid required to scavenge $50 \%$ of DPPH radicals.

\section{Hydroxyl radical scavenging assay}

An in vitro method employed by Jiang et al. ${ }^{27}$ was performed to investigate the hydroxyl radical scavenging activity of various concentrations viz. $6.25-200 \mu \mathrm{g} / \mathrm{ml}$ of ripe and unripe fruit extract of $R$. steudneri. The absorbance of reaction mixture was measured at $532 \mathrm{~nm}$. Ascorbic acid was used as reference standard. The scavenging of hydroxyl radicals (\%) by fruit extracts was calculated using the formula:

Hydroxyl radical scavenging activity $(\%)=1$ - (absorbance of sample/ absorbance of blank) x 100. $\mathrm{IC}_{50}$ value for fruit extracts as well as ascorbic acid was calculated. $\mathrm{IC}_{50}$ value denotes the concentration of fruit extract/ ascorbic acid required to scavenge $50 \%$ of hydroxyl radicals.

\section{Lipid peroxidation inhibition assay}

The protocol described by Badmus et al. ${ }^{28}$ was used to determine inhibition of lipid peroxidation by different concentrations $(6.25-200 \mu \mathrm{g} / \mathrm{ml})$ of fruit extracts and ascorbic acid (reference standard) by estimating the thiobarbituric acid reactive substances (TBARS). The absorbance of reaction mixtures was measured at $532 \mathrm{~nm}$. The inhibition of lipid peroxidation (\%) was calculated using the formula:

Lipid peroxidation inhibition $(\%)=(C-T / C) \times 100$, where ' $C$ ' and ' $T$ ' represents to absorbance of control and absorbance of test respectively. $\mathrm{IC}_{50}$ value was calculated and the $\mathrm{IC}_{50}$ value represents the concentration of fruit extract/ascorbic acid required to produce a 50\% inhibition of lipid peroxidation.

\section{Statistical analysis}

All experimental determinations were carried out in triplicates $(n=3)$. The results are represented as Mean \pm Standard deviation (S.D). $\mathrm{IC}_{50}$ value for extracts and reference standard was calculated by linear regression analysis using Origin (Data Analysis and Graphing) Software version 7.0 for windows.

\section{RESULTS AND DISCUSSION}

\section{Phytochemicals detected in ripe and unripe fruit extracts}

Plants produce a myriad of primary and secondary metabolites. The secondary metabolites belong to different classes of compounds such as alkaloids, polyphenols and terpenoids and are distributed in various parts of the plant such as root, leaves, flower and seeds. The medicinal and pharmacological properties of plants are due to the presence of these secondary metabolites as indicated by several studies. Conventional and nonconventional methods have been widely used to extract plant materials. Several methods such as standard phytochemical tests, GC-MS, HPLC and other chromatographic and spectral analyses have been employed to screen the plants for the presence of secondary metabolites. ${ }^{29-33}$ The preliminary phytochemical analysis of extract of ripe and unripe fruit of R. steudneri is shown in Table 1. Ripe fruit extract was found to possess all phytochemicals tested while unripe fruit extract was shown to contain all phytochemicals except glycosides.

\section{Scavenging of DPPH radicals by ripe and unripe fruit extracts}

Among various in vitro antiradical assays, DPPH assay is one of the most widely used assays as it is simple, inexpensive, rapid, and the results obtained are reproducible. This method was originally described by Blois. DPPH radical is a nitrogen centred organic free radical having purple color and shows an absorption maximum at 515-520nm in alcoholic solutions. On interacting with a substance with proton donating property (an antioxidant), the radical is converted into DPPHH and the color changes from purple to yellow (diphenylpicrylhydrazine). This method is widely used to evaluate antiradical potential of plant extracts. ${ }^{4-6,34-37}$ In the present study, we determined the antiradical activity of ripe and unripe fruit extract of $R$. steudneri by DPPH assay and the results are shown in figure 2. It was observed that the extract exhibited concentration dependent scavenging of radicals. Radical scavenging of $>50 \%$ was observed at extract concentration of $25 \mu \mathrm{g} / \mathrm{ml}$ and higher while ascorbic acid displayed scavenging activity of $>50 \%$ at concentration $12.50 \mu \mathrm{g} / \mathrm{ml}$. Both the extracts displayed more or less similar scavenging activity, however, marked scavenging potential was displayed by ripe fruit extract $\left(\mathrm{IC}_{50}\right.$ value $16.04 \mu \mathrm{g} / \mathrm{ml}$ ) when compared to unripe fruit extract $\left(\mathrm{IC}_{50}\right.$ value $\left.18.65 \mu \mathrm{g} / \mathrm{ml}\right)$. When compared to fruit extracts, ascorbic acid displayed higher scavenging potential as it scavenged DPPH radicals dose dependently with an $\mathrm{IC}_{50}$ value of $14.18 \mu \mathrm{g} / \mathrm{ml}$. At $200 \mu \mathrm{g} / \mathrm{ml}$ concentration, the scavenging activity observed was $93.19 \%, 97.51 \%$ and $100 \%$ in case of ripe fruit extract. It is clear from the result that the fruit extracts possess hydrogen donating and radical scavenging ability and thereby they can act as primary antioxidants. In an earlier study, 
Tadesse et al..$^{20}$ found DPPH scavenging potential of solvent extracts of R. stuedneri leaves with marked activity being exhibited by $80 \%$ methanol extract followed by acetone and methanol extracts. In another study, Tauchen et al. ${ }^{21}$ showed the potential of $80 \%$ ethanol extract of roots and leaves and twigs of $R$. steudneri to scavenge DPPH radicals.

\section{Scavenging of hydroxyl radicals by ripe and unripe fruit extracts}

The hydroxyl radicals are the chemically most reactive species of activated oxygen and are formed by successive reduction of molecular oxygen during metabolism. Hydroxyl radicals are primarily responsible for the cytotoxic effects of oxygen in animals, plants as well as microorganisms. Hydroxyl radicals unspecifically attacks the biomolecules such as polysaccharides, nucleic acids and proteins located less than a few nanometers from their site of generation and are known to be involved in a number of cellular disorders such as inflammation, embryo teratogenesis and cell death, and killing microorganisms during pathogen-defense reactions. These radicals are also involved in initiation of lipid peroxidation. Hydroxyl radicals are produced by Fenton reaction which involves the reaction between hydrogen peroxide and metal ions. The removal of hydroxyl radicals by their scavenging seems to be very important antioxidant activity and several studies have revealed the promising effects of extracts from many plants to scavenge hydroxyl radicals..$^{4,27,38,39,40}$ The result of scavenging of hydroxyl radicals by ripe fruit and unripe fruit extract of R. steudneri is shown in Figure 3. Both the extracts displayed

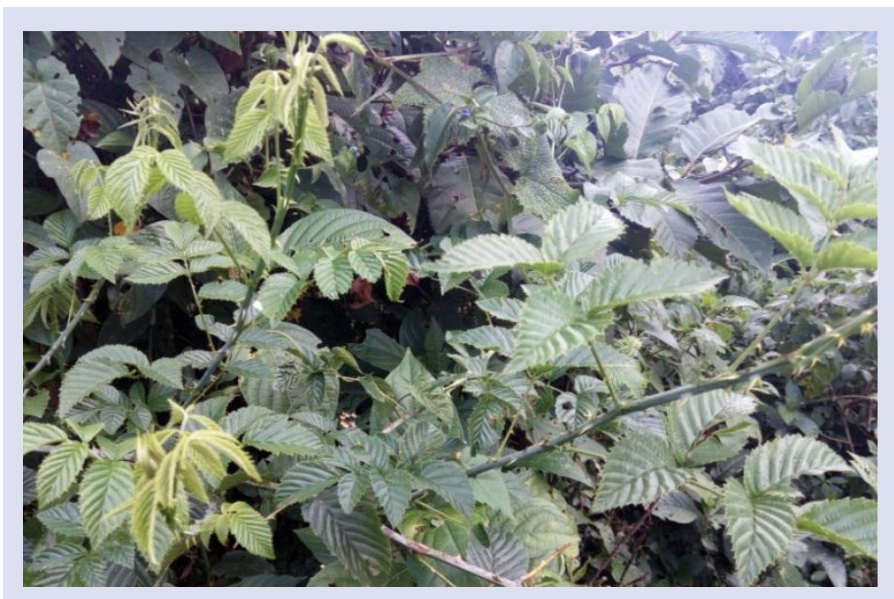

Figure 1: Rubus steudneri (Photograph by Raghavendra H.L)

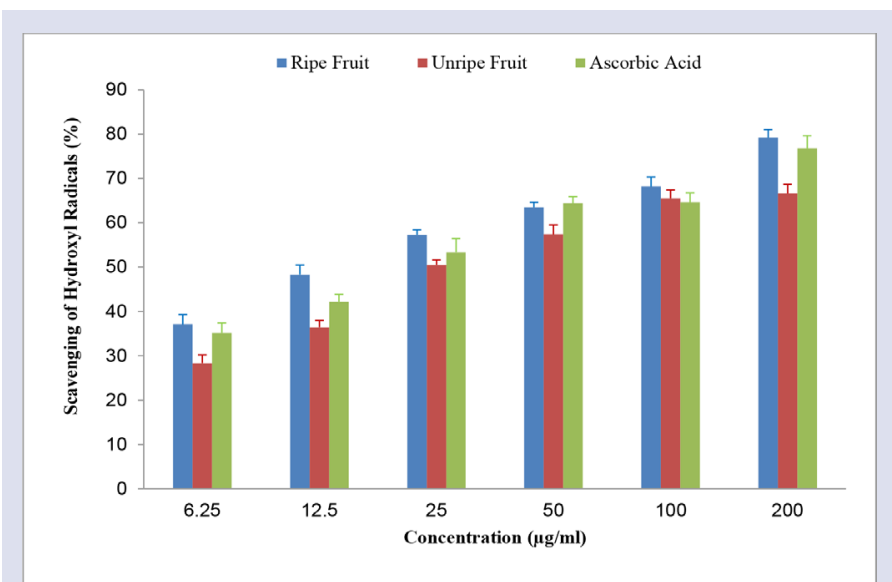

Figure 3: Scavenging of hydroxyl radicals by ripe and unripe fruit extracts marked and concentration dependent scavenging of hydroxyl radicals. A scavenging activity of $50 \%$ and higher was recorded at extract concentration of $25 \mu \mathrm{g} / \mathrm{ml}$ and higher in case of both extracts and ascorbic acid. At concentration $200 \mu \mathrm{g} / \mathrm{ml}$, the scavenging activity displayed by ripe fruit, unripe fruit and ascorbic acid was found to be $79.19 \%, 66.61 \%$ and $76.81 \%$ respectively. Based on $\mathrm{IC}_{50}$ value, the scavenging potential was in the order: ripe fruit extract $\left(\mathrm{IC}_{50}\right.$ value $\left.16.95 \mu \mathrm{g} / \mathrm{ml}\right)>$ ascorbic acid $\left(\mathrm{IC}_{50}\right.$ value $22.37 \mu \mathrm{g} / \mathrm{ml})>$ unripe fruit extract $\left(\mathrm{IC}_{50}\right.$ value $\left.24.45 \mu \mathrm{g} / \mathrm{ml}\right)$.

\section{Inhibition of lipid peroxidation by ripe and unripe fruit extracts}

It is shown that the lipid peroxidation process occurs through free radical chain reactions and results in damage caused to biological membrane leading to significant loss of membrane functioning. Lipid radicals are formed by the reaction between lipids and free radicals. On interacting with the molecular oxygen, it further forms lipid peroxyl radicals. These radicals continue the peroxidation process by extracting hydrogen atoms from other lipid molecules. Substances (antioxidants) with the ability to donate hydrogen can disturb this propagation process and thereby such compounds inhibit lipid peroxidation. It is evident that plants exhibit lipid peroxidation inhibition property which is mainly through radical scavenging property. ${ }^{\mathbf{2 8 , 4 1 - 4 4}}$ In the present study, we evaluated the potential of fruit extracts of $R$. steudneri to inhibit lipid peroxidation. Figure 4 shows lipid peroxidation inhibitory activity of ripe fruit and unripe fruit extracts of $R$. steudneri. Both extracts displayed marked

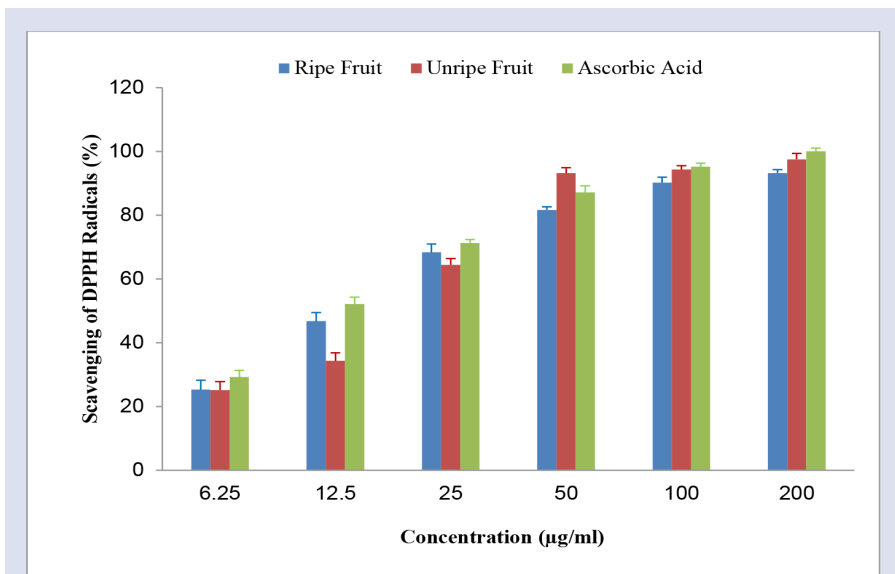

Figure 2: Scavenging of DPPH radicals by ripe and unripe fruit extracts

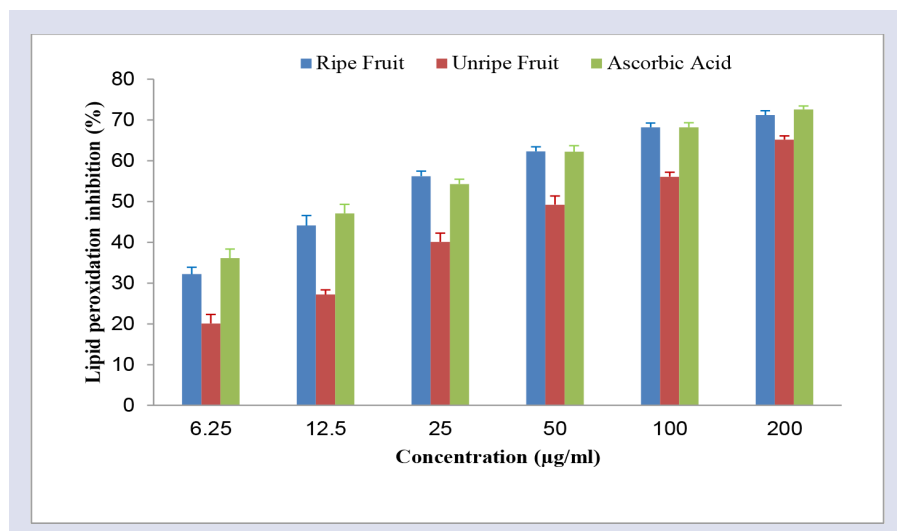

Figure 4: Inhibition of lipid peroxidation by ripe and unripe fruit extracts 
Raghavendra, et al.: Raghavendra, et al.: Antiradical and Lipid Peroxidation Inhibitory Activity of Rubus steudneri

Table 1: Phytochemicals detected in ripe and unripe fruit of $R$. steudneri

\begin{tabular}{ccc}
\hline Phytochemical & Ripe fruit & Unripe fruit \\
\hline Glycosides & + & - \\
Saponins & + & + \\
Alkaloids & + & + \\
Phenolic compounds & + & + \\
Flavonoids & + & + \\
Tannins & + & + \\
Sterols & + & + \\
Triterpenoids & + & + \\
\hline
\end{tabular}

inhibition of lipid peroxidation in a concentration dependent manner. Extract from ripe fruit exhibited stronger inhibitory effect on lipid peroxidation when compared to unripe fruit extract. An inhibitory activity of $50 \%$ and higher was recorded at concentration of $25 \mu \mathrm{g} / \mathrm{ml}$ and $100 \mu \mathrm{g} / \mathrm{ml}$ of ripe and unripe fruit extract respectively. At $200 \mu \mathrm{g} / \mathrm{ml}$ concentration, only ripe fruit extract and ascorbic acid displayed $>70 \%$ inhibition of lipid peroxidation. The inhibitory activity against lipid peroxidation by fruit extracts and ascorbic acid was in the order: ascorbic acid $\left(\mathrm{IC}_{50}\right.$ value $\left.19.69 \mu \mathrm{g} / \mathrm{ml}\right)>$ ripe fruit extract $\left(\mathrm{IC}_{50}\right.$ value $\left.21.31 \mu \mathrm{g} / \mathrm{ml}\right)$ $>$ unripe fruit extract $\left(\mathrm{IC}_{50}\right.$ value $\left.70.96 \mu \mathrm{g} / \mathrm{ml}\right)$.

\section{CONCLUSION}

Both ripe and unripe fruit of $R$. steudneri exhibited marked concentration dependent radical scavenging and lipid peroxidation inhibitory activity. Overall, ripe fruit extract displayed stronger antiradical and lipid peroxidation inhibitory activity when compared to unripe fruit extract. The free radical scavenging nature of extract could be related to the lipid peroxidation inhibitory potential of extracts. The observed bioactivities could be ascribed to the presence of flavonoids and phenolic compounds detected in the fruit extracts. In suitable form, the fruit of $R$. steudneri can be developed as therapeutic agent against oxidative damage caused by free radicals.

\section{CONFLICTS OF INTEREST}

The authors declare no conflict of interest.

\section{ABBREVIATIONS}

IC: Inhibitory concentration; DPPH: 2,2-diphenylpicryl-1-hydrazyl; GC-MS: Gas chromatography-Mass spectrometry; HPLC: High-performance liquid chromatography; BHA: Butylated hydroxyanisole; BHT: Butylated hydroxytoluene; TBARS: thiobarbituric acid reactive substances.

\section{REFERENCES}

1. Bandoniene $D$, Murkovic M. The detection of radical scavenging compounds in crude extract of borage (Borago officinalis L.) by using an on-line HPLC-DPPH method. J Biochem Biophys Methods 2002;53(1-3):45-9.

2. Scalbert A, Johnson IT, Saltmarsh M. Polyphenols: antioxidants and beyond. Am J Clin Nutr. 2005;81(1):215S-7S.

3. Gorinstein S, Vargas OJ, Jaramillo NO, Salas IA, Ayata AL, Arancibia-Avila P, et al. The total polyphenols and the antioxidant potentials of some selected cereals and pseudocereals. European Food Research and Technology. 2007;225(3-4):321-8

4. Li P, Huo L, Su W, Lu R, Deng C, Liu L, et al. Free radical-scavenging capacity, antioxidant activity and phenolic content of Pouzolzia zeylanica. J Serb Chem Soc. 2011;76(5):709-17.

5. Aliyu AB, Ibrahim MA, Musa AM, Musa AO, Kiplimo J, Oyewale AO. Free radical scavenging and total antioxidant capacity of root extracts of Anchomanes difformis Engl. (Araceae). Acta Poloniae Pharmaceutica - Drug Research.
2013;70(1):115-21

6. Hmid I, Elothmani D, Hanine H, Oukabli A, Mechinagic E. Comparative study of phenolic compounds and their antioxidant attributes of eighteen pomegranate (Punica granatum L.) cultivars grown in Morocco. Arabian Journal of Chemistry. 2017; 10:S2675-84

7. Lulekal E, Rondevaldova J, Bernaskova E, Cepkova J, Asfaw Z, Kelbessa E, et al. Antimicrobial activity of traditional medicinal plants from Ankober District, North Shewa Zone, Amhara Region, Ethiopia. Pharm Biol. 2014;52(5):614-20.

8. Quattrocchi U. CRC world dictionary of medicinal and poisonous plants: Common names, scientific names, eponyms, synonyms, and etymology (5 volume set). CRC Press, New York. 2016;3265

9. Rothman JM, Dierenfeld ES, Molina DO, Shaw AV, Hintz HF, Pell AN. Nutritional chemistry of foods eaten by gorillas in Bwindi Impenetrable National Park, Uganda. American Journal of Primatology. 2006;68(7):675-91.

10. Yineger $H$, Kelbessa $E$, Bekele $T$, Lulekal $E$. Plants used in traditional management of human ailments at Bale Mountains National Park, Southeastern Ethiopia. J Med Plants Res. 2013;2(6):132-53.

11. Giday M, Asfaw Z, Woldu Z. Medicinal plants of the Meinit ethnic group of Ethiopia: An ethnobotanical study. J Ethnopharmacol. 2009;124(3):513-21.

12. Kamoga D. Some pharmacological activities of selected medicinal plant species used for treating cattle diseases in Kabira sub-county, Rakai district. M.Sc dissertation, Makerere University, Uganda. 2010.

13. Kefalew A, Asfaw Z, Kelbessa E. Ethnobotany of medicinal plants in Ada'a District, East Shewa Zone of Oromia Regional State, Ethiopia. J Ethnobiol Ethnomed. 2015;11(1):25

14. Mesfin F, Demissew S, Teklehaymanot T. An ethnobotanical study of medicinal plants in Wonago Woreda, SNNPR, Ethiopia. J Ethnobiol Ethnomed 2009;5(1):28.

15. Senbeta F, Gole TW, Denich M, Kellbessa E. Diversity of useful plants in the coffee forests of Ethiopia. Ethnobotany Research and Applications. 2013;11:4969.

16. Yassin S, Abera B, Kelbessa E. Ethnobotanical study of indigenous knowledge of plant-material culture in Masha and Yeki districts, Southwest Ethiopia. African Journal of Plant Science. 2015;9(2):25-49.

17. Alemayehu G, Asfaw Z, Kelbessa E. Plant diversity and ethnobotany in Berehet District, North Shewa Zone of Amhara Region (Ethiopia) with emphasis on wild edible plants. Journal of Medicinal Plants Studies. 2015;3(6):93-105.

18. Ashagre M, Asfaw Z, Kelbessa E. Ethnobotanical study of wild edible plants in Burji District, Segan Area Zone of Southern Nations, Nationalities and Peoples Region (SNNPR), Ethiopia. J Ethnobiol Ethnomed. 2016;12(1):32.

19. Amente DA. Ethnobotanical survey of wild edible plants and their contribution for food security used by Gumuz people in Kamash Woreda; Benishangul Gumuz Regional State; Ethiopia. Journal of Food and Nutrition Sciences. 2017:5(6):217-24

20. Tadesse S, Asres K, Veeresham C. Antioxidant activities of three Rubus species growing in Ethiopia. Ethiop Pharm J. 2007;25:103-10.

21. Tauchen J, Doskocil I, Caffi C, Lulekal E, Marsik P, Havlik J, et al. In vitro antioxidant and anti-proliferative activity of Ethiopian medicinal plant extracts. Industrial Crops and Products. 2015;74:671-9.

22. Kekuda PTR, Raghavendra HL, Shilpa M, Pushpavathi D, Petkar T, Siddiqua A Antimicrobial, antiradical and insecticidal activity of Gardenia gummifera L. F. (Rubiaceae). Int J Pharm Pharm Sci. 2017;9(10):265-72.

23. Tiwari P, Kumar B, Kaur M, Kaur G, Kaur H. Phytochemical screening and extraction: A review. Internationale Pharmaceutica Sciencia. 2011;1(1):98-106.

24. Arya V, Thakur N, Kashyap CP. Preliminary phytochemical analysis of the extracts of Psidium leaves. J Pharmacogn Phytochem. 2012;1(1):1-5

25. Jaradat N, Hussen F, Al Ali A. Preliminary phytochemical screening, quantitative estimation of total flavonoids, total phenols and antioxidant activity of Ephedra alata Decne. J Mater Environ Sci. 2015;6(6):1771-8.

26. Chandrashekar VM, Muchandi AA, Sudi SV, Muchandi IS. Free radical scavenging activity of Stereospermum suaveolens DC: An in-vitro evaluation. Pharmacologyonline. 2009;1:50-6.

27. Jiang $X$, Meng $Y$, Liang $Y, X i a o ~ Z$. Evaluation of the antioxidant and antibacterial activities of various solvent extracts from Passiflora wilsonii Hemsl. Biotechnology. 2015;14(3):129-35

28. Badmus JA, Adedosu TO, Fatoki JO, Adegbite VA, Adaramoye OA, Odunola OA Lipid peroxidation inhibition and antiradical activities of some leaf fractions of Mangifera indica. Acta Pol Pharm. 2011;68(1):23-9.

29. Dillard CJ, German BJ. Phytochemicals: Nutraceuticals and human health. J Sci Food Agric. 2000;80(12):1744-56.

30. Kaufmann B, Christen P. Recent extraction techniques for natural products: Microwave-assisted extraction and pressurised solvent extraction. Phytochem Anal. 2002;13(2):105-13

31. Yusuf AZ, Zakir A, Shemau Z, Abdullahi M, Halima SA. Phytochemical analysis of the methanol leaves extract of Paullinia pinnata linn. J Pharmacogn Phytother. 2014;6(2):10-6.

32. Zhang Y, Gan R, Li S, Zhou Y, Li A, Xu D, et al. Antioxidant phytochemicals for the prevention and treatment of chronic diseases. Molecules. 2015;20(12):21138-56.

33. Kabera JN, Semana E, Mussa AR, He X. Plant secondary metabolites: Biosyn- 
thesis, classification, function and pharmacological properties. J Pharm Pharmacol. 2014;2:377-92.

34. Hsu H, Houng J, Chang C, Wu C, Chang F, Wu Y. Antioxidant activity, cytotoxicity, and DNA information of Glossogyne tenuifolia. J Agric Food Chem. 2005;53(15):6117-25.

35. Sharma OP, Bhat TK. DPPH antioxidant assay revisited. Food Chem. 2009; $113(4): 1202-5$

36. Kedare SB, Singh RP. Genesis and development of DPPH method of antioxidant assay. J Food Sci Technol. 2011;48(4):412-22.

37. Manasa M, Vivek MN, Kambar Y, Kumar RKA, Kekuda PTR. Mineral content, antimicrobial and radical scavenging potential of Caesalpinia mimosoides Lamk. (Caesalpiniaceae). World J Pharm Res. 2014;3(4):1047-63.

38. Chen S, Schopfer P. Hydroxyl-radical production in physiological reactions. A novel function of peroxidase. Eur J Biochem. 1999;260(3):726-35.

39. Samak G, Shenoy RP, Manjunatha SM, Vinayak KS. Superoxide and hydroxy radical scavenging actions of botanical extracts of Wagatea spicata. Food Chem. 2009;115(2):631-4.
40. Zou Y, Zhao Y, Hu W. Chemical composition and radical scavenging activity of melanin from Auricularia auricula fruiting bodies. Food Sci Technol, Campinas. 2015;35(2):253-8.

41. Desmarchelier C, Mongelli E, Coussio J, Ciccia G. Inhibition of lipid peroxidation and iron (II)-dependent DNA damage by extracts of Pothomorphe peltata (L.) Miq. Braz J Med Biol Res. 1997;30:85-91.

42. Nandhakumar $E$, Indumathi P. In vitro antioxidant activities of methanol and aqueous extract of Annona squamosa (L.) fruit pulp. J Acupunct Meridian Stud. 2013;6(3):142-8

43. Phaniendra A, Jestadi DB, Periyasamy L. Free Radicals: Properties, sources, targets, and their implication in various diseases. Indian $\mathrm{J}$ Clin Biochem. 2015;30(1):11-26.

44. Adefegha SA, Oboh G. In vitro inhibition activity of polyphenol-rich extracts from Syzygium aromaticum (L.) Merr. \& Perry (Clove) buds against carbohydrate hydrolyzing enzymes linked to type 2 diabetes and Fe $(2+)$-induced lipid peroxidation in rat pancreas. Asian Pac J Trop Biomed. 2012;2(10):774-81.
GRAPHICAL ABSTRACT

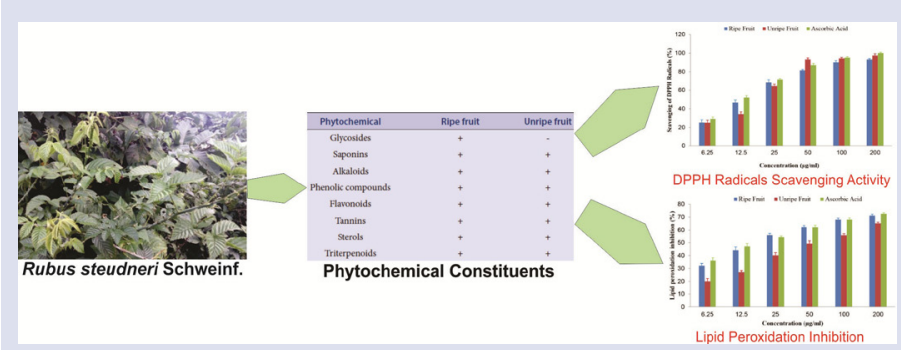

\section{SUMMARY}

- Rubus steudneri is an important medicinal plant (native to Africa) belonging to the family Rosaceae. The fruit of $R$. steudneri is edible and is consumed in different parts of Africa. The present study revealed marked antiradical and lipid peroxidation inhibitory activity of ripe and unripe fruit extract of $R$. steudneri. Overall, the ripe fruit extract displayed marked activity when compared to unripe fruit extract. The study appears promising as the edible fruit of $R$. steudneri is shown to exhibit potent antioxidant activity indicating its possible role in therapy against free radical induced damage.

\section{ABOUT AUTHORS}

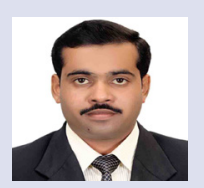

Dr. Raghavendra H.L, M.Sc., Ph.D. is presently serving as an Associate Professor in the Department of Biochemistry, School of Medicine, Wollega University, Nekemte, Ethiopia.

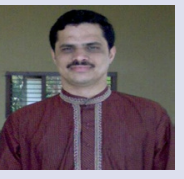

Dr. PrashithKekuda T.R, M.Sc., Ph.D. is currently working as a faculty in the Department of Microbiology, S.R.N.M.N College of Applied Sciences, Shivamogga, Karnataka, India.

Cite this article: Raghavendra HL, Kekuda PTR. Antiradical and Lipid Peroxidation Inhibitory Activity of Ripe and Unripe Fruit of Rubus steudneri Schweinf. (Rosaceae). Pharmacog J. 2018;10(4):818-22. 